\title{
The Challenges Faced by Pre-Service Mathematics Teachers during their Teaching Practice in the UAE: Implications for Teacher Education Programs
}

\author{
Adeeb M. Jarrah \\ United Arab Emirates University, United Arab Emirates \\ https://orcid.org/0000-0002-8216-8848
}

\begin{abstract}
Teaching practice is a fundamental component of teacher education programs, not only because it provides student teachers with first-hand experience, but also because it is an opportunity for them to put into action everything they have learned about education and their subject matter. Thus, the purpose of this study was to investigate the challenges that encounter pre-service mathematics teachers during their teaching practice in the United Arab Emirates (UAE). A qualitative phenomenological approach was used. Data for this research were collected through semi-structured interviews with fourteen participants at the end of their teacher education program. A thematic content analysis was performed on the content of interview transcripts to identify common themes. The emerging themes revealed that participants had serious concerns and they encountered various difficulties during teaching practice. Notable findings included participants' difficulties transferring theoretical knowledge into practice, lack of availability of manipulatives, challenges with student discipline and classroom management, difficulty experimenting with innovative pedagogical practices, and concerns regarding the structure and the timing of the student teaching program. For student teachers to emerge at the end of their teaching practice as qualified and confident professional teachers, it is imperative that teacher preparation programs and school administrators reflect on the findings of this study. The study concluded with recommendations to direct future research.
\end{abstract}

Keywords: Teaching Challenges; Student Teacher; Classroom Management; Student Discipline; Teacher Training

\section{Introduction}

The teaching of mathematics, or any subject, for that matter, is a multifaceted task. To do this successfully, students need and deserve knowledgeable teachers, who are willing to learn about their students as learners of mathematics, and to acquire the skills, disposition, and instructional strategies needed to teach the subject (Kilpatrick \& Swafford, 2001). To achieve this goal, teacher training has become a 
top priority in many countries, including the United Arab Emirates (UAE), where the preparation of well-qualified teachers is one of the eight pillars of the UAE's educational development vision (Vision 2021, 2017). Specifically, the vision for 2021 is to ensure that all of the UAE's private and public schools have highly qualified teachers who are sensitive to the needs of a diverse student population, dedicated to high-quality learning experiences for all students, and committed to life-long professional learning and growth (Vision 2021, 2017). Thus, teacher education programs must examine the process of preparing pre-service mathematics teachers, including their readiness, attitudes, competency, and teaching practice.

Teaching practice is a fundamental component of teacher education programs, not only because it provides student teachers with first-hand experience, but also because it is an opportunity for them to put into action everything they have learned about education and their subject matter (Maphosa, Shumba \& Shumba, 2007; Abdullah, Omar, Embong \& Bakar, 2015; Trent, 2013). Teaching practice exposes student teachers to the real world of teaching and acquaints them with the complexity of classroom practice, thus contributing to their future orientation towards the teaching profession (Fajardo \& Miranda, 2015). However, teaching practice is also a challenging experience (Ferrier-Kerr, 2009; Trent, 2013), and for this reason it is important to ensure that student teachers are supported as well as possible. Therefore, the focus of this study is to uncover the challenges faced by pre-service mathematics teachers during their teaching practice in the UAE.

Thus, this research adds knowledge to the literature on the challenges student teachers encounter during their teaching practice in Emirati elementary schools, since no such study was found upon reviewing the related literature. The research may benefit those dealing with teacher preparation programs, and may also provide school administrators with a better understanding of student teachers' needs during this essential phase of their teacher preparation.

\section{Literature Review}

A review of the literature was conducted concerning the challenges encountered by pre-service teachers during their student teaching. It is worth noting that the terms teaching practice, practicum, or student teaching are often used interchangeably in the literature (Grootenboer, 2006).

\subsection{Teaching practice}

As is generally true, teaching practice in the United Arab Emirates University (UAEU) context is one of the most important elements of a teacher education program, and it is expected that a student teacher will gain valuable experience from it. Once student teachers complete their coursework, composed of 126 credit hours, they practice teaching in schools for one semester of 16 weeks. During this teaching practice period, student teachers must demonstrate mastery of all standards for beginner teachers accepted by the teacher education program in the College of Education. Students are expected to spend a full semester of practice teaching in an elementary school. During this time, they are expected to gather experience of certain duties and roles as part of their induction to teaching, and it 
is also intended that they develop and understand the knowledge and skills required in more depth. However, little is known about what transpires during this essential period of a UAEU student teacher's life because of a lack of research within the UAE context (Ibrahim, 2013).

\subsection{Challenges of Pre-service Teachers}

The literature reports several challenges experienced by pre-service teachers. One of these relates to theoretical knowledge to teaching practice in real classroom settings, and this problem has been reported as a major concern (Gan, 2013; Peercy, 2012). For example, Gan (2013) reported that pre-service teachers voiced difficulties about applying the theory studied in their coursework to their classroom practice. According to Peercy (2012), pre-service teachers do not use the theories they learn on training programs, and face difficulty bridging the gap between theory and practice. A second issue reported in the literature by preservice teachers concerns the availability and use of manipulatives. Educators believe physical objects help students enjoy learning, keep them engaged, and narrow the gap between abstract and concrete concepts (Furner \& Worrell 2017; Cockett \& Kilgour; 2015; Larbi \& Mavis, 2016). As a learning resource, the use of manipulatives encourages students to engage with learning in concrete ways. However, in a study in the Philippines, Ulla (2016) indicated that a lack of teaching resources prompted pre-service teachers to recycle strategies and methods. In another study on teachers' beliefs and teaching mathematics with manipulatives, Golafshani (2013) recommended that schools provide teachers with resources to increase the use of manipulatives, to provide teachers with a greater range of teaching strategies in their classroom situations.

A third issue which has emerged in the literature as a challenge for pre-service teachers is classroom management, since student teachers only have a theoretical rather than practical knowledge of this area. This issue tends to be compounded by a lack of guidance and cooperation by schools on classroom management for pre-service teachers (Moussaid \& Zerhouni, 2017). In a study conducted by Han and Ye (2015), it was suggested that pre-service teachers encounter many difficulties in China regarding classroom management, when teaching students learning English for university. These very problematic experiences in the classroom may be ascribed to the fact that the pre-service teacher's authority is lower than fully trained and experienced teachers (Foncha, Abongdia \& Adu, 2015). Furthermore, student teachers can experience a great deal of anxiety about managing the classroom, and this may cause serious problems with their posttraining classroom management (Foncha, Abongdia \& Adu, 2015).

A fourth concern seen in the previous research relates to pedagogic challenges. In a study by Moussaid and Zerhouni (2017), pre-service teachers encountered various difficulties, one of which was teaching methodology. Under this umbrella, they included lesson planning and delivery, lack of teaching experience, managing lesson pace and transitions, contextualization and modelling, and lack of pedagogical content knowledge. In another study, Gökçek (2018) investigated sixty-one pre-service teachers who had enrolled in a compulsory six-hour teaching practicum. The study concluded that the pre-service teachers faced 
several challenges, including the use of activities, materials, methods, and techniques, and instilling an affection for mathematics. In a study on the impact of a school-based practicum on pre-service teachers' affective development in mathematics, although forty per cent of the participants had positive views of their experience after practicum, fifty per cent were neutral Grootenboer (2006). These studies indicate that student teachers' general experience of pre-service teaching could be improved.

In this regard, student teaching programs must be structured to provide trainees with experiences that help them to develop and grow into professional teachers (Johnson, 2015). Various researchers have described what an effective structure for student teaching should necessitate. First, long training duration is preferred in many different countries such as Jordan and China (Han \& Ye, 2015; Hamidi, Al-Shara, Arouri \& Abu Awwad, 2014). In Jordan, this preference might be because pre-service teachers first need to become acquainted with the school system, and then with the teaching systems and styles (Hamidi, Al-Shara, Arouri \& Abu Awwad, 2014). In China, pre-service teachers lamented how short training programs are insufficient, since by the time they become familiar with a school, the program has ended (Han \& Ye, 2015). In a comparative study of practicum experiences in ten universities, Manzar-Abbas and Lu (2013) notably reported that the duration of the practicum is short and its timing inappropriate. They therefore recommended increasing the duration and sending student teachers into schools much earlier.

The above summary and discussion of the literature indicate that teaching practice is crucial for the personal and professional development and growth of pre-service teachers (Azhar \& Kayani, 2017). Therefore, the need to investigate and improve the impact of their experience is key. The main purpose of the present study is thus to investigate the challenges that encounter pre-service mathematics teachers during their teaching practice in the UAE.

\subsection{Research Question}

The study sought to answer the following question:

What challenges do pre-service mathematics teachers encounter during their teaching practice?

\section{Methodology}

\subsection{Research design}

The purpose was to explore the lived experiences and challenges of a group of pre-service mathematics teachers during teaching practice. To this end, the phenomenological approach was considered appropriate since it would allow participants to describe their lived experiences freely, and thus provide specific insights. The phenomenological approach would also contribute to a more profound understanding of these challenges. According to Creswell (2013: 76), "phenomenological study describes the common meaning for several individuals of their lived experiences of a concept or a phenomenon". Phenomenological research is typically conducted through in-depth interviews, in which 
participants have the freedom to express their views in their own terms (Creswell, 2007). For this reason, the study used semi-structured interviews for the data collection.

\subsection{Participants}

The fourteen female participants of this study were all senior students enrolled in their final semester of the elementary education program in the College of Education at the UAEU. The rationale for focusing on just fourteen pre-service teachers was because they were the only available students in their final two years. Participants were therefore chosen based on purposive sampling.

\subsection{Data collection}

The researcher conducted individual interviews in Arabic as participants were native Arabic speakers, and the interview time was approximately 45-60 minutes each. Participants were briefed about the purpose of the interviews and the nature of the research, and given assurances about ethical considerations such as confidentiality; they were also told that they could terminate the interview at any time. All interviews were audio-recorded for later use, after consent forms had been given. To protect the identities of the participants, the researcher abbreviated each participant by the code PMT plus a number, i.e. PMT1-PMT14.

\subsection{The Research Instrument}

To gather detailed information about the lived experience of the participants, it was essential to construct questions that covered different dimensions of teaching practice, and which would provide descriptive answers. Two general questions were developed based on a review of the relevant literature and the researcher's experience in teaching and learning mathematics. Thus, open-ended questions were constructed to encourage participants to share concerns and views. Specifically, the following two questions were used as a general outline:

- What challenges did you encounter during your teaching practice?

- What strategies did you use to overcome the challenges you encountered?

Additionally, participants' answers were often explored further with follow-up questions, to obtain more information, further clarification, or specific examples.

\subsection{Data Analysis}

Prior to analysis, the collected data were transcribed from the audio recording, and then analyzed using Thematic Content Analysis (TCA) to identify the emergent themes (Anderson, 2007). With TCA, similar patterns and views found in the data are gathered and put into categories, and these are then placed under specific themes. It is worth mentioning that the researcher completed the data analysis process independently before the same process was repeated by another colleague to improve the quality and credibility of the findings.

\section{Results}

Table 1 illustrates the results for the first research question on the challenges faced by pre-service mathematics teachers during their teaching practice. Participants' perspectives formed five important themes. 
Table 1. Themes \& Samples of Quotations by Mathematics Pre-Service Teachers

\begin{tabular}{|c|c|c|}
\hline Theme & PMT & Samples of Quotations by Participants \\
\hline \multirow[t]{2}{*}{$\begin{array}{l}\text { 1. Relating Theory } \\
\text { to Practice }\end{array}$} & PMT1 & $\begin{array}{l}\text { "I feel that there are a number of courses that talked } \\
\text { about many theories and I did not benefit from during } \\
\text { my student teaching." }\end{array}$ \\
\hline & PMT5 & $\begin{array}{l}\text { "I had very limited exposure to actual classrooms } \\
\text { during my training to relate the theories studies to the } \\
\text { reality of teaching." }\end{array}$ \\
\hline \multirow{3}{*}{$\begin{array}{l}\text { 2. Availability of } \\
\text { Manipulatives }\end{array}$} & PMT3 & $\begin{array}{l}\text { "The school where I was placed to do my student } \\
\text { teaching did not have enough manipulatives to } \\
\text { demonstrate mathematical concepts to students." }\end{array}$ \\
\hline & PMT4 & $\begin{array}{l}\text { "Lack of Support in Terms of Materials and } \\
\text { Equipment." }\end{array}$ \\
\hline & РMT9 & $\begin{array}{l}\text { "My professor taught us how to teach mathematical } \\
\text { concepts with concrete objects ... but what I needed was } \\
\text { not available." }\end{array}$ \\
\hline \multirow{4}{*}{$\begin{array}{l}\text { 3. Student } \\
\text { Discipline and } \\
\text { Classroom } \\
\text { Management }\end{array}$} & PMT7 & $\begin{array}{l}\text { "My students thought I was there to visit or play, not to } \\
\text { teach ...that is why they did not listen and they were } \\
\text { misbehaving." }\end{array}$ \\
\hline & PMT9 & $\begin{array}{l}\text { "Students did not keep quiet and I spent a lot of time } \\
\text { trying to make them quiet...because of that I did not } \\
\text { finish my lessons." }\end{array}$ \\
\hline & PMT11 & "It was very difficult to manage my class because my \\
\hline & PMT13 & $\begin{array}{l}\text { "I tried to apply what I learned from courses to manage } \\
\text { students...I felt I need more strategies to control them." }\end{array}$ \\
\hline \multirow{4}{*}{$\begin{array}{l}\text { 4. Pedagogical } \\
\text { Challenges }\end{array}$} & PMT8 & $\begin{array}{l}\text { "I felt like the students were not engaged because I was } \\
\text { afraid to suggest innovative teaching methods to my } \\
\text { cooperative teacher." }\end{array}$ \\
\hline & PMT10 & $\begin{array}{l}\text { "Students struggle with some mathematical terms } \\
\text { because of their lack of language." }\end{array}$ \\
\hline & PMT13 & $\begin{array}{l}\text { "I had one student with special needs...I was not sure } \\
\text { if I was doing the right thing dealing with him." }\end{array}$ \\
\hline & PMT14 & $\begin{array}{l}\text { "I struggled with lesson planning because we were } \\
\text { trained in English but we had to teach in Arabic." }\end{array}$ \\
\hline \multirow{3}{*}{$\begin{array}{l}\text { 5. Student } \\
\text { teaching } \\
\text { structure }\end{array}$} & PMT8 & $\begin{array}{l}\text { "I was scared and I felt I was not part of the school at } \\
\text { the beginning of the experience." }\end{array}$ \\
\hline & PMT9 & $\begin{array}{l}\text { "One semester is not enough. We should be exposed to } \\
\text { teaching much earlier in our program." }\end{array}$ \\
\hline & PMT2 & $\begin{array}{l}\text { "I did not gain much experience regarding what } \\
\text { happens in staff meetings because I was excluded from } \\
\text { such meetings." }\end{array}$ \\
\hline
\end{tabular}

\section{Theme 1. Relating Theory to Practice}

Two participants thought that several university courses they completed during their undergraduate program were too theoretical, and failed to provide them with the means to cope with the realities of the classroom. As one participant stated, "I feel that there are a number of courses that talked about many theories and I did not benefit from these during my student teaching" (PMT1). Another participant stated that some university courses were about theory without any connection to actual 
classroom practice. PMT5 believed that she "...had very limited exposure to actual classrooms during training to relate the theories studies to the reality of teaching."

\section{Theme 2. The Availability of Manipulatives}

Participants stated how they had learned that the use of manipulatives is very effective for enhancing student understanding. However, three participants believed that the lack of these manipulatives had hindered their performance as mathematics teachers. PMT3 stated that, "The school where I was placed to do my student teaching did not have enough manipulatives to demonstrate mathematical concepts to students." Similarly, the availability of manipulatives as a challenge was echoed by PMT 9, who said "My professor taught us how to teach mathematical concepts with concrete objects ...but what I needed was not available."

\section{Theme 3. Student Discipline and Classroom Management}

Student discipline and classroom management was the most frequently mentioned challenge by participants. They highlighted their lack of management skills and how difficult it was to teach disruptive students. Participants' comments regarding this challenge were as follows:

"My students thought I was there to visit or play, not to teach ... that is why they did not listen and they were misbehaving." (PMT7)

"Students did not keep quiet and I spent a lot of time trying to make them quiet...because of that I did not finish my lessons." (PMT9)

"It was very difficult to manage my class because my students did not think of me as a real teacher." (PMT11)

"I tried to apply what I had learned from courses to manage students...I felt I need more strategies to control them." (PMT13)

\section{Theme 4. Pedagogical Challenges}

Regarding pedagogical challenges, participants felt that they were not comfortable suggesting or trying a different teaching methodology than the one used by the cooperative teacher. As one participant explained, "I felt like the students were not engaged because I was afraid to suggest innovative teaching methods to my cooperative teacher" (PMT8). Another participant thought the students' limited English proficiency had negative effects on her pedagogical practices. One participant pointed out, "Students struggle with some mathematical terms because of their lack of language" (PMT10). Another participant lacked confidence when she was interacting with a special needs student, and commented, "I was not sure if I was doing the right thing dealing with him" (PMT13).

A fourth participant noted that she faced difficulty planning and delivering a quality lesson because she was trained in a different language to the one she was using for teaching. Participant PMT14 thus explained, "I struggled with lesson planning because we were trained in English, but we had to teach in Arabic."

\section{Theme 5. Student teaching structure}

The interviewed teachers reflected on the structure of how student teachers were allowed to practice teaching, and pointed out several issues with its current 
format. Participant PMT2 believed that one semester of teaching might not be enough to gain the skills needed, and she stated, "I did not gain much experience regarding what happens in staff meetings, because I was excluded from such meetings." Another participant reinforced this belief, saying that "One semester is not enough. We should be exposed to teaching much earlier in our program" (PMT9). These and other participants felt that exposure to a school setting much earlier would help them to avoid being scared, as PMT8 expressed when she said, "I was scared, and I felt I was not part of the school at the beginning of the experience."

\section{Discussion and Conclusion}

The aim of this study was to explore the challenges encountered by pre-service mathematics teachers during their student teaching period, and in this regard, the in-depth interviews uncovered several important challenges. While all the student teachers in this study indicated that they benefited from the experience of teaching practice, they also experienced challenges which may have affected their ability to grow, and to learn what teaching as a profession entails. It is, therefore, necessary to address and overcome these challenges to avoid any negative effect on student teachers' perceptions of becoming a teacher.

First, with regard to relating theory to practice, and as shown in the interview excerpt, the participants commented that university courses helped them gain an overview of certain pedagogical theories, but crucially they did not know how to translate this knowledge to the classroom. The challenge of relating theory to practice has also been documented by other studies (Gan, 2013; Peercy, 2012). Indeed, since the 1960s, the disparity between university coursework and the realities of teaching practice has been a consistent issue (Cochran-Smith, 2005; Korthagen, 2010). However, teacher educators are yet to find an effective way to bridge the gap between theory and practice. The responses of this sample of interviewees may suggest that the teacher preparation program they experienced is either unfamiliar with what is needed in schools, or does not provide enough opportunities to practice what was learned. Thus, supporting the learning of student teachers requires that the teacher preparation program links student teaching experience in schools with on-campus coursework (Darling-Hammond, 2006).

The finding on the lack of availability of manipulatives may be why these student teachers did not feel innovative and had difficulty engaging students. This is in line with Ulla (2016), who also found that a lack of teaching resources for preservice teachers meant that they recycled strategies and methods. Moreover, the participants in this study echoed Golafshani's recommendation that schools provide teachers with manipulatives to use as teaching strategies that fit their classroom situation (2013). Furthermore, the availability of manipulatives is an effective tool in mathematics instruction because students can visualize the mathematical concepts before they are introduced to them in the abstract form (Furner \& Worrell, 2017).

One serious obstacle faced by these student teachers was how to manage classrooms and control students. As shown in the interview excerpts, the 
participants mentioned these obstacles more than any other topic, and they specifically commented on the difficulty of teaching lessons because students were disruptive and the classroom became difficult to manage. Nguyen, Tran, and Luu (2017) reported similar results, and indicated that student teachers view classroom management as a major challenge, particularly student misbehavior, in the practicum context. Other studies have reported similar results, and suggest that this challenge may have a negative impact on student teachers' views of the teaching profession (Uibu, Salo, Ugaste \& Rasku-Puttonen, 2017; Gan, 2013). The large number of student teachers who report issues with classroom management may be linked to the fact that they have theoretical knowledge, but lack the chance to put it into practice during the earlier part of their preparation programs. These results point to an urgent need for embedding classroom management techniques into the curricula of teacher education programs, rather than maintaining the traditional focus on theories.

The challenge of pedagogical and content knowledge was also a concern expressed by the student teachers during their teaching practice. In this case, however, the challenge was being afraid to apply some of the more innovative teaching methods they had learned in their preparation program due to potential conflict with the cooperative teacher. This finding is similar to Gan's study (2013), which noted the difficulty of experimenting with the innovative pedagogical practices learned on their methodology courses. In the current study, the findings also revealed that the student teachers lacked the confidence to choose appropriate teaching strategies with special needs students. Equipping student teachers with strategies for dealing with special need students is extremely important because the UAE has adopted a law which places such students in mainstream education. As shown in the interview excerpt, one participant said that the reason she faced difficulty was the language of instruction, as she had been trained in English but was using Arabic in her student teaching.

Finally, while all participants stated that they had benefited greatly from the experience, they also had concerns regarding the structure of the training program, and reported that one semester was insufficient to become acquainted with the requirements and practice of teaching. Similar results about the duration of student teaching were reported by Mutlu (2014). Additionally, participants expressed a desire to be exposed to the experience of teaching earlier in their preparation program, rather than waiting until the very last semester. Again, this is similar to the findings of Mutlu (2014), who reported that student teachers thought their teaching practice should start in the second or third year of their preparation program.

To summarize, this study has explored the challenges faced by pre-service mathematics teachers during their teaching practice in the UAE. To achieve the intended objective, fourteen participants from the College of Education at the UAEU were interviewed. The results indicated that pre-service teachers encountered several challenges: relating theory to practice; the availability of manipulatives; student discipline and classroom management; pedagogical challenges; and, the structure of the program for student teachers. 


\section{Implications and Future Research}

This study has value for teacher education programs throughout the UAE because it provides different institutions with an opportunity to evaluate the strengths and weaknesses of their student teaching program. The voices emerging from this study require teacher education programs to re-examine their practices both on and off-campus. Specifically, the findings point to the need for teacher educators to be vigilant about the content of their coursework, and how it translates to meaningful practices in schools. Furthermore, it is necessary for teacher education programs to listen to their trainee teachers and the challenges they face during the student teaching period. For student teachers to emerge at the end of their teaching practice as qualified and confident professional teachers, and to improve how they are prepared, it is essential to explore and overcome the challenges they face during this key period. Future research should, therefore, complement this study by exploring the challenges from the point of view of cooperating teachers and university supervisors.

This study has some limitations which must be acknowledged. Specifically, the results of the study may not be generalized due to the small sample size and the research method employed. Larger scale studies with different research methodology may yield more concrete results.

\section{References}

Abdullah, A. H., Omar, M. C., Embong, R., \& Bakar, N. S. A. (2015). The Perception Towards Practicum Experience among Islamic Education Pre-service Teachers in University Sultan Zainalabidin (UnisZA), Terengganu, Malaysia. Middle-East Journal of Scientific Research, 23(4), 695-705. doi:10.5829/idosi.mejsr.2015.23.04.22158

Al-Awidi, H. M., \& Alghazo, I. M. (2012). The effect of student teaching experience on preservice elementary teachers' self-efficacy beliefs for technology integration in the UAE. Educational Technology Research and Development, 60(5), 923-941. doi:10.1007/s11423-012-9239-4

Anderson, R. (2007). Thematic content analysis (TCA): descriptive presentation of qualitative data.

Retrieved from http://www.wellknowingconsulting.org/publications/pdfs/ThematicContent Analysis.pdf

Azhar, M., \& Kayani, M. M. (2017). Study of the Impact of Training of Novice Teachers in the Context of Transformative Learning in Punjab, Pakistan. Advanced Education, 4(8), 84-91. doi:10.20535/2410-8286.112533

Cansiz, N. (2015). The Challenges Faced by Pre-service Science Teachers During Teaching Practice. The Eurasia Proceedings of Educational \& Social Sciences (EPESS), 2, 40-42.

Castañeda-Trujillo, J. E., \& Aguirre-Hernández, A. J. (2018). Pre-Service English Teachers' Voices About the Teaching Practicum. HOW Journal, 25(1), 156-173. doi:10.19183/how.25.1.420

Cochran-Smith, M. (2005). Studying teacher education: What we know and need to know. Journal of Teacher Education, 56, 301-307. doi:10.1177/0022487105280116

Cockett, A., \& Kilgour, P. W. (2015). Mathematical Manipulatives: Creating an Environment for Understanding, Efficiency, Engagement, and Enjoyment. Teach Collection of Christian Education, 1(1), 47-54 
Creswell, J. W. (2013). Qualitative Inquiry and research design: choosing among five approaches (3rd Ed). Thousand Oaks, CA: Sage Publications.

Creswell, J. W. (2007). Qualitative inquiry \& research design: Choosing among five approaches (2nd ed.), Thousand Oaks, CA: Sage Publications.

Darling-Hammond, L. (2006). Powerful teacher education: Lessons from exemplary programs. San Francisco, CA: Jossey-Bass

Ferrier-Kerr, J. L. (2009). Establishing professional relationships in practicum settings. Teaching and Teacher Education, 25(6), 790-797. doi:10.1016/j.tate.2009.01.001

Foncha, J. W., Abongdia, J.-F. A., \& Adu, E. O. (2015). Challenges Encountered by Student Teachers in Teaching English Language during Teaching Practice in East London, South Africa. International Journal of Educational Sciences, 9(2), 127-134. doi:10.31901/24566322.2015/09.02.04

Furner, J. M., \& Worrell, N. L. (2017). The importance of using manipulatives in teaching math today. Transformations, 3(1), 1-25. Retrieved from https:/ / nsuworks.nova.edu/cgi/viewcontent.cgi?article=1013\&context=transfo rmations/

Gan, Z. (2013). Learning to teach English language in the Practicum: What challenges do non-native ESL student teachers face? Australian Journal of Teacher Education, 38(3), 92-108. doi:10.14221/ajte.2013v38n3.3

Gan, Z., \& Yang, C.C.R. (2018). How prepared are the pre-service ESL teachers to teach: Insights from university supervisor feedback. Journal of Asia TEFL, 15, 99-117. doi:10.18823/asiatefl.2018.15.1.7.99

Ganal, N. N., Andaya, O. J. F., \& Guiab, M. R. (2015). Problems and difficulties encountered by student teachers of Philippine Normal University Isabela Campus. International Journal of Science and Engineering, 1(9), 63-74.

Gökçek, T. (2018). Examining Mathematics Pre-service Teachers' Experiences of School Practicum. Journal of Education and Training Studies, 6(8), 87-95. doi:10.11114/jets.v6i8.3264

Golafshani, N. (2013). Teachers' Beliefs and Teaching Mathematics with Manipulatives. Canadian Journal of Education, 36(3), 137-159

Grootenboer, P. (2006). The impact of the school-based practicum on pre-service teachers' affective development in mathematics. Mathematics Teacher Education and Development, 7(1), 18-32

Hamaidi D., Al-Shara I. , Arouri, Y., \& Awwad, F. A., (2014) Student-teachers' perspectives of practicum practices and challenges. European Scientific Journal 10(13), 191-214

Ibrahim, A. S. (2013). Approaches to supervision of student teachers in one UAE teacher education program. Teaching and Teacher Education, 34, 38-45. doi:10.1016/j.tate.2013.04.002

Johnson, K. R. (2015). Fourth Year Pre-service Teachers' Perceptions of the Student Teaching Practicum in Abu Dhabi (Doctoral Dissertation). Walden University. Retrieved from

http:/ / scholarworks.waldenu.edu/cgi/viewcontent.cgi?article=2890\&context= dissertations

Kilpatrick, J., \& Swafford, J. (Eds.). (2001). Adding it up: Helping children learn mathematics. Washington, D. C.: National Academy Press.

Koross, R. (2016). The student teachers' experiences during teaching practice and its impact on their perception of the teaching profession. IRA International Journal of Education and Multidisciplinary Studies, 5(2), 76-85. doi:10.21013/jems.v5.n2.p3

Korthagen, F. A. J. (2010). How teacher education can make a difference. Journal of Education for Teaching, 36, 407-423. doi:10.1080/02607476.2010.513854 
Larbi, E., \& Mavis, O. (2016). The use of manipulatives in mathematics education. Journal of Education and Practice, 7(36), 53-61.

Mahmood, N., \& Iqbal, Z. (2018). Challenges Faced by Prospective Teachers during Teaching Practice: Connecting Theory to Practice. Bulletin of Education and Research, 40(2), 113-136.

Manzar-Abbas, S., \& Lu, L. (2013). Keeping the practicum of Chinese pre-service teacher education in world's perspective. International Journal of Academic Research in Business and Social Sciences, 3(4), 172-186

Maphosa, C., Shumba, A., \& Shumba, J. (2007). Mentorship for students on teaching practice in Zimbabwe: Are student teachers getting a raw deal? South African Journal of Higher Education, 2, 296-307. doi:10.4314/sajhe.v21i2.25637

Moussaid, R., \& Zerhouni, B. (2017). Problems of Pre-Service Teachers During the Practicum: An Analysis of Written Reflections and Mentor Feedback. Arab World English Journal, 8(3), 135 -153. doi:10.24093/awej/vol8no3.10

Mutlu, G. (2014). Challenges in practicum: Pre-service and cooperating teachers' voices. Journal of Education and Practice, 5(36), 1-7

Muzindutsi, P. F., \& Khanare, P. F. (2018). Challenges Experienced by Pre-Service Teachers in the Post-Graduate Certificate in Education Programme at a South African University. Dirasat: Educational Sciences, 45(4), 584-593. doi:10.35516/0102-045988-031

Nguyen, N. T., Tran, H. A., \& Luu, L. N. (2017). Classroom management: Difficulties facing fast-track teacher-trainees in the tutoring program. The English Teacher, $45(2), 84$ - 95

Peercy, M. M. (2012). Problematizing the theory-practice gap: How ESL teachers make sense of their pre-service education. Journal of Theory and Practice in Education, 8(1), $20-40$.

Trent, J. (2013). From learner to teacher: Practice, language, and identity in a teaching practicum. Asia-Pacific Journal of Teacher Education, 41(4), 426-440. doi:10.1080/13598 66X.2013.838621

Uibu, K., Salo, A., Ugaste, A., \& Rasku-Puttonen, H. (2017). Beliefs about teaching held by student teachers and school-based teacher educators. Teaching and Teacher Education, 63, 396-404. doi:10.1016/j.tate.2017.01.016

Ulla, M. B. (2016). Pre-service teacher training programs in the Philippines: The studentteachers practicum teaching experience. EFL journal, 1(3), 235-250. doi:10.21462/eflj.v1i3.23

Quick, G., \& Siebörger, R. (2005). What matters in practice teaching? The perceptions of schools and students. South African Journal of Education, 25(1), 1-4.

Vision2021 (2017). First rate education. Available at: https://www.vision2021.ae/en/statements/firstrate-education

Yan, C., \& He, C. J. (2015). “We Are Left in Limbo!” Chinese EFL student teachers' teaching practicum experience. Frontiers of Education in China, 10(2), 226-250 doi:10.3868/s110-004-015-0016-5 